Revista ELectrónica de Investigación y EValuación Educativa
RELIEVE
e-Journal of Educational Research, Assessment and Evaluation

ISSN: 1134-4032

\title{
Student involvement in assessment: involving the whole student in pursuit of social justice and the social good
}

Participación e implicación del estudiante en la evaluación: implicar a todo el estudiante en la búsqueda de la justicia y el bien social

\author{
McArthur, J. \\ Lancaster University
}

\begin{abstract}
In this article I offer a perspective on student involvement in assessment informed by critical theory and underpinned by a commitment to greater social justice within and through higher education. It builds on earlier work on assessment for social justice to argue that student involvement in assessment must be considered more broadly than simply students doing particular tasks. Instead, we must think of the student as a whole person, socially situated, and the ways in which engagement with assessment tasks nurtures both individual and social wellbeing. There are three streams to the argument proposed. Firstly, that scholarship on assessment should do more to problematise the nature of knowledge and that understanding the complexities of knowledge in higher education has links to both the experiences of our student as a whole person and social justice. Secondly, that the purposes of assessment should be orientated to the critical theory notion of a social good, in which individual and social wellbeing are dialectically inter-related. Finally, in thinking of the student's involvement in assessment we must go beyond the conflation of the real world with the world of work which features in much of the literature on authentic assessment. Instead, I propose the importance of understanding the economic realm as a broad and heterogenous sphere and one that cannot be disarticulated from the social realm.
\end{abstract}

Keywords: Student involvement; Critical Theory; Social good; Social justice; Authentic assessment; Student achievement; Honneth; Mutual recognition; Responsive assessment

\begin{abstract}
Resumen
En este artículo ofrezco una perspectiva sobre la implicación y participación de los estudiantes en la evaluación informada por la teoría crítica y respaldada por un compromiso con una mayor justicia social dentro y a través de la educación superior. Se basa en un trabajo anterior sobre evaluación para la justicia social para argumentar que la participación e implicación de los estudiantes en la evaluación debe considerarse de una manera más amplia que simplemente la realización de tareas concretas. En cambio, debemos pensar en el estudiante como una persona completa, socialmente situada, y las formas en que el compromiso con las tareas de evaluación fomenta el bienestar tanto individual como social. Hay tres corrientes para el argumento propuesto. En primer lugar, que los estudios sobre evaluación deberían hacer más para problematizar la naturaleza del conocimiento, y que comprender las complejidades del conocimiento en la educación superior tiene vínculos tanto con las experiencias de nuestro estudiante como persona integral como con la justicia social. En segundo lugar, que los propósitos de la evaluación deben estar orientados a la noción de la teoría crítica de un bien social, en el que el bienestar individual y social están dialécticamente interrelacionados. Finalmente, al pensar en la implicación y participación del estudiante en la evaluación, debemos ir más allá de la confluencia del mundo real con el mundo del trabajo que figura en gran parte de la literatura sobre evaluación auténtica. En cambio, propongo la importancia de entender el ámbito económico como amplio y heterogéneo que no puede separarse del ámbito social.
\end{abstract}

Palabras clave: Participación del estudiante; Teoría crítica; Bienestar social; Justicia social; Evaluación auténtica; Rendimiento del estudiante; Honneth; Reconocimiento mutuo; Evaluación respondente

\begin{tabular}{ll|l|l|l|l}
\hline Received/Recibido 2020 Abr 14 & Approved /Aprobado 2020 June 03 & Published/Publicado 2020 June 24 \\
\hline
\end{tabular}


In this article I offer a perspective on student involvement in assessment informed by critical theory and underpinned by a commitment to greater social justice within and through higher education. I suggest a radical expansion of both our understanding of student involvement in assessment and in the related concept of authentic assessment. Grounded in the notion of assessment for social justice (McArthur, 2016, 2018) this article explores the inextricable link between the nature of assessment and students' fulfilment as independent members of society. This argument reflects one of the defining features of critical theory, which is the dialectical interrelationship between individual and social wellbeing. Thus, when we ask the question 'what role can and should students have in assessment?', the answer goes well beyond involvement in discrete tasks. Rather, our focus shifts to the ways in which assessment does, or does not, enable individual student fulfilment and a sense of self.

I therefore want to extend the notion of student involvement to think in terms of the whole student: to think philosophically about the relationship between assessment and students' self-realisation. To say that students are involved in assessment thus means more than that they do a bit of assessment. Indeed, perhaps instead we can turn this around and consider the extent to which assessment is involved in our students: the extent to which it contributes, or not, to their wellbeing, personal and intellectual growth and their development as constructive members of society. In fact, I argue that there is a fundamental link between assessment and social justice - and our students are at the heart of this. This link is based on a simple premise: if assessment shapes how and what students learn, as the literature suggests, and if we are committed to social justice within and through higher education, then surely assessment is key to the achievement of that social justice.

The idea of students being actively involved in assessment tasks, rather than simply passive recipients, is well-established in the literature on peer and self-assessment (e.g. Boud et al., 1999; Falchikov \& Goldfinch, 2000; Liu \& Carless, 2006; Orsmond et al., 2000). Indeed peer and self assessment are clearly the most common forms of student involvement in the assessment process (Falchikov \& Goldfinch, 2000). Student involvement is also central to much of the literature on assessment literacy, highlighting how students must be actively supported to be informed actors in the assessment processes they encounter (Carless \& Boud, 2018; Douglas Smith et al., 2013). Furthermore, the general issue of student involvement is compatible with the broader and evolving literature on student-staff partnerships (Bovill, 2013; Bovill et al., 2011a; 2011b). Indeed, Bovill's work in this area explicitly links back into assessment tasks in her study, with Deeley, of student-staff partnerships and the development of assessment literacy (Deeley \& Bovill, 2017).

Student involvement in assessment can be seen across countries and across disciplines including science, technology, engineering and maths (STEM), arts and humanities and education and social sciences (Falchikov \& Goldfinch, 2000). In addition, such student involvement has ranged from pre-courses stages, through the degree levels and into ongoing professional practice (Falchikov \& Goldfinch, 2000).

The rationale for these forms of student involvement in assessment are strong and rest on three main reasons. Firstly, that student involvement improves their learning. Secondly, that it improves assessment performance. Finally, that it nurtures skills, knowledge and dispositions important for life beyond university. This provides our link to authentic assessment as it too is focused on undertaking assessment tasks with future relevance, sometimes described as real world tasks (Ashford-Rowe et al., 2014; James \& Casidy, 2018; Villarroel et al., 2018). My point of departure here, however, is based on a critique of much of this literature and in particular an assumption that prevails which casts 'real world' as synonymous with the 
world of work. I do not want to deny the importance of work to students' individual and social wellbeing, however, it is wrong to have an understanding of higher education either based on a narrow sense of the economic sphere or an understanding of the economic disarticulated from the social (McArthur, 2011, 2016).

Applying the critical theory of Axel Honneth (Honneth, 1996, 2003, 2004b) and his notion of mutual recognition I explore the relationship between assessment practices and students' capacities to develop as members of society recognised for the traits and abilities they have to contribute to the broader social good. I therefore position assessment, in terms of both its procedures and practices, as a powerful force in shaping individual students' identity and sense of self-worth. We must involve the whole student in our thinking about assessment because assessment is about who they are and who they go on to be in our society.

This position builds on my earlier work on assessment for social justice (McArthur, 2016, 2018). Here I have argued that we must rethink assessment both philosophically and practically to harness its enormous potential in realising greater social justice within and through higher education. But the monograph, Assessment for Social Justice, was always intended to start a conversation, not be the last word in one. I therefore turn in this paper to explicitly address the question of student involvement in assessment from an assessment for social justice perspective, which is itself informed by critical theory.

I argue that the most important way in which to understand student involvement in assessment is to appreciate and foster the role that assessment plays in developing students as both individuals and active and fulfilled citizens. Thus we shift our focus from the tasks that students are involved in and instead have as a primary concern the person the student becomes through engagement with assessment. And, in line with critical theory, that person is understood firmly within a social context.
There are, therefore, three elements to my argument for thinking of student involvement in assessment as being about the whole person and their potential to live a socially fulfilling life. The first is to argue we need to think more about the nature of knowledge when we discuss assessment, and this position harks back to my earlier work on the nature of knowledge and social justice in higher education (McArthur, 2013). The second aspect draws on my work on assessment for social justice (McArthur, 2016, 2018) and the extent to which assessment tasks enables students to further their own individual wellbeing by making a positive social contribution through the skills and attributes they develop. This reflects the dialectical relationship between individual and society at the heart of critical theory. Finally, the concept of society itself is examined to ensure that we do not fall into neoliberal tendencies to equate the world of work with society, but rather see the former as an aspect of the latter.

\section{Knowledge, Assessment and Social Justice}

In an earlier work I explore the relationship between knowledge in higher education and social justice, inspired by the work of early critical theorist Theodor Adorno (see McArthur, 2013). I argue that there are four qualities associated with the nature of knowledge which are essential if we are committed to greater social justice within and through higher education. Firstly, this knowledge must be not easy to know. By this I mean that higher education is, in part, defined by the complex, contested and dynamic forms of knowledge which we research, teach, learn and assess. Secondly, students (and researchers) must be active participants in the processes of engaging with knowledge. Here we pick up the theme of this article, of involving the whole student. As Brown and Duguid (2000) so powerfully establish, knowledge, unlike information, is embodied and therefore we must understand that it changes with the knower and also changes the knower. This means that there is risk and uncertainty at the heart of engagement with 
complex knowledge. And assessment should reflect this. Thirdly, I call for places where we can escape the mainstream and the status quo: to be beyond what Adorno refers to as 'the passive acceptance of what is merely the case' (Adorno, 2001, p. 121). A socially-just university cannot simply reproduce canon as though static fact. And yet, what are the possibilities for moving towards social justice from within a system that is unjust? This is a central conundrum in Adorno's critical theory. Here, I argue, higher education has an important role to play. Finally, I suggest that our understanding of knowledge should itself be based on a particular understanding of theory and practice. Here the influence of Adorno is particularly strong as it was a central preoccupation of his, particularly in the years before his death, to rally against the separation of theory and practice and to argue instead for their dialectical interconnection.

This work on higher education, knowledge and social justice is in many ways a prequel to my current work on assessment for social justice. But the relationship between the two is actually a dynamic one, and thinking about students' involvement in assessment causes me to reassess some aspects of my previous work on knowledge in higher education. I stand by these four features as fundamental to thinking about social justice in higher education, however, I also acknowledge that so far I have treated knowledge within higher education as though there are no differences between the knowledge which we engage with as researchers, the knowledge we teach through the curriculum and the knowledge students engage with when they undertake assessment tasks. This needs remedying. Here I draw on Bernstein's (2000) concept of the 'pedagogic device' to bring greater complexity to my analysis, and to reinforce the point that in thinking about assessment we need to think about the student as a whole person.

Bernstein is important if we are considering social justice and knowledge because of the way in which he sees knowledge in terms of sites of struggle between different versions of legitimacy and different players (researchers, teachers and students). Central to Bernstein's analysis is the idea that it is mistaken to assume that the knowledge we engage with when we research, when we teach the curriculum and when students engage in assessment practices is the same. Rather there are processes of interpretation, legitimatisation and transformation through each of these stages. Shay (2008) describes the pedagogic device as 'a "relay" constituted by a series of rules which determine how knowledge is produced, recontextualised and evaluated' (601). There are three rules: firstly, distributive rules determine which knowledge is regarded as important; secondly, recontextualising rules are responsible for the transformation of knowledge into the curriculum; finally, evaluative rules, being the sum of all rules, tell us what counts as legitimate engagement with knowledge or 'texts'. As Shay explains, Bernstein uses the term texts in a very specific way which has important repercussions. By texts he means anything that is evaluated so this can include not just a piece of written text, but 'use of the body, manner of speaking, even dress' (Shay, 2008, p. 601). This, Shay argues, means that: 'the specialisation of certain kinds of knowledge is at the same time the specialisation of certain kinds of knowers. Evaluative criteria not only legitimate texts, they legitimate knower identities' (601). This is why we must think of assessment in terms of our student as a whole person.

Ashwin has interpreted Bernstein's pedagogic device to delineate three different forms of knowledge: knowledge-as-research, knowledge-as-curriculum and knowledge-asstudent-understanding (Ashwin, 2014; Ashwin et al., 2012). Because of that process of transformation the knowledge changes in each context - and legitimately so. And yet, of course, they are not unrelated: there are some characteristics of the discipline evident in each of the forms of knowledge. From Shay's perspective, the implication of this is the possibility of a theoretically rigorous approach to ensuring valid and reliable assessment criteria. This is done by reflecting on the 
extent to which the evaluative rules are consistent with their epistemic roots in the site of knowledge production and its further recontextualization into curriculum and pedagogy. Thus the evaluative rules (assessment criteria) which shape knowledgeas-student-understanding retain some family resemblance to knowledge-as-research or knowledge-as-curriculum. If they do not then arguably the assessment is problematic and has not achieved its goals. Though my point of departure from Shay rests in her 'quest for a theory which grants knowledge a status independent of knowers' (p. 600). To be clear, Shay does acknowledge that knowledge is socially mediated, but from a critical realist perspective also seeks to establish its objective character. My critical theory perspective is different, seeing knowledge as neither absolute nor relativist, but as embodied and constructed through human experience.

As sites of struggle these three forms of knowledge are thus the outcome of power, class and control. To achieve the four qualities of knowledge for social justice I have previously outlined, we need to appreciate what happens at these sites of struggle, and this gives further emphasis to the point that we cannot assume knowledge is benign or easily known.

What is at the heart of social justice and knowledge, is that students are not passive recipients of static canon. They are participants in these sites of struggle. But, the question that worries me, is to what extent students are aware of this? To move towards greater social justice, students must understand these processes of transformation between knowledge-as-research, knowledge-ascurriculum and knowledge-as-studentunderstanding.

Thus while I acknowledge the legitimacy of research and practice that seeks to improve students' assessment literacy, I again suggest that this does not go far enough in terms of how students should be involved in assessment. Moreover, there is a danger of a fairly technocratic approach to understanding rubrics, marking criteria or assessment processes in contrast to an explicit engagement with the complexities of disciplinary knowledge. This danger was highlighted some years ago by Norton (2004) and reinforced by Shay (2008) in her analysis of the relevance of Bernstein's pedagogic device to assessment. Moreover, if we think of knowledge through the lens of the pedagogic device then this massively problematises how and why we engage with practices such as drawing up assessment criteria or marking rubrics. We should neither attempt to assess knowledge-asstudent-understanding as if it is knowledge-asresearch (i.e. make no concessions between the knowledge we engage with as researchers and what we expect our students to do) nor allow the two to be unrecognisable from one another (in Shay's terms, this is the way to account for the elusive concept of standards in assessment processes).

Shay is rare as a higher education scholar who has worked across both the problematisation of knowledge and our understandings of assessment. Too much assessment literature assumes that knowledge is just 'there' and the challenge is how to get students to learn it. Despite the de rigueur acknowledgement of constructivist theories of learning in much assessment literature, the unproblematic treatment of knowledge actually has echoes of what Freire (1996) critiqued as 'bankable' approaches to education: where students are empty vessels into which this thing called knowledge is simply poured. What Shay (2008) has demonstrated is that even in social constructivist approaches to teaching, learning and assessment the nature of knowledge is often insufficiently problematised.

As Ashwin (2014) explains:

knowledge-as-research, knowledge-ascurriculum and knowledge-as-studentunderstanding offers a powerful way of gaining a sense of the transformative power of higher education because it brings into focus the ways in which higher education transforms students' 
understanding and identities. This involves developing a deeper sense of how students' engagement with knowledge and curriculum can transform their relations with themselves and the world. (p. 124).

When a student engages with an assessment task, they are engaging with knowledge. In turn, that engagement is a transformative process and, in many different ways, can shape that student's identity and their relation to society. This is why the significance of assessment practices in higher education goes well beyond the well-intentioned aims of the assessment for learning movement. The problem with much of this literature is that knowledge is unproblematised and student involvement focuses on discrete tasks and not the student as a whole, social person, who is in turn shaped by engaging with that complex and contested knowledge.

\section{Social Good - Individual and Social Wellbeing}

Central to the critical theory perspective which informs this article is the dialectical inter-relationship between individual and social wellbeing. Indeed, while critical theory has changed over time from the first generation work of Horkheimer, Adorno and Marcuse through to Habermas's second generation and now the third generation work of Axel Honneth, an enduring feature of all these theorists is this relationship between self and society (Honneth, 2004a). Honneth terms this 'co-operative self-actualisation'. Thus if our aim is to ensure each individual achieves their potential to live a flourishing life (an aim common to progressive theories of social justice including both critical theory and the capabilities approach) then this can only be achieved through social belonging. This is very different to the concept of the individual at the heart of most liberal theories.

Horkheimer made this link between individual and social clear when he became director of the Institute for Social Research (Frankfurt School) in 1931. Thus he said in his famous speech upon taking up his Directorship: "Its [Institute for Social Research] ultimate aim is the philosophical interpretation of the vicissitudes of human fate - the fate of humans not as mere individuals, however, but as members of a community" (Horkheimer, 1993, p. 1). He goes on to say: "The destiny of the particular is fulfilled in the fate of the universal; the essence or substantive form of the individual manifests itself not in its personal acts, but in the life of the whole to which it belongs" (Horkheimer, 1993, pp. 2-3). In Honneth's work the connection between individual and social wellbeing is apparent in the three inter-connected realms of mutual recognition which underlie his plural theory of social justice. Thus, Honneth states that we know what is just by: "that which allows the individual member of our society to realize his or her own life's objectives, in cooperation with others, and with the greatest possible autonomy" (Honneth, 2010, p. 13).

I have used Honneth as a theoretical foundation for my work on assessment for social justice because he provides such a useful and operationalizable conception of social justice. He does so by detailing three, interrelated realms of mutual recognition: love, respect and esteem (Honneth, 2004b). Each of these in their different ways reflects this interplay between social and self. Love recognition is about primary relationships, and is the foundation for our recognition as individuals of worth. Thus it is about the relationship between a particular father and his son or a woman and her sister. In my own work on assessment for social justice I have extended Honneth's concept beyond family relations as such but retained that emphasis on particularity. Thus, I argue, that it is essential to just pedagogical relationships, including assessment practices, that we are committed to values such as trust and honesty not with teachers or students in some general sense, but in an embodied sense related person to person (McArthur, 2018).

Respect recognition has a universal quality and refers to the rights that we all have as 
citizens. But more than this, it is about knowing one has such rights, understanding them and actively using them. In so doing one functions as a fully-fledged member of the community. In an assessment context, I have used this to consider the importance of students having genuine responsibility for their own assessment practices and achievements. This means that they must be fully literate in not just marking criteria and so on, but in the rules and regulations that govern their assessment lives. They also need to appreciate decisions about assessment, and what counts as legitimate knowledge, as socially situated and subject to debate and contestation.

Finally, in the concept of esteem recognition we have a particularly strong resonance with knowledge engagement and assessment practices. Esteem recognition relates to the possession of traits and abilities with which to make a positive contribution to the social whole. Thus Honneth links it to a notion of solidarity. It has an individual quality, in that it refers to the different traits and abilities that individuals have: we cannot say meaningfully that everyone is equally good at everything. In addition, this is about mutual recognition, so it is about having these traits and abilities, recognising this in oneself and having it recognised by others.

In a large on-going study with a group of colleagues 1 I have looked at the ways in which students self-identify a sense of achievement through their assessment work. This is important because, in light of Honneth's notion of esteem recognition, students should be given opportunities to develop skills and attributes, through the engagement with knowledge, that can be recognised as sociallyuseful and which they recognise as such in themselves. While analysis of this comparative and longitudinal project involving Chemistry and Chemical Engineering students in the UK, South Africa and USA is on-going,

1 Understanding Knowledge, Curriculum and Student Agency, funded by the ESRC, Office for Students and Research England. Project team members are: Paul Ashwin (Principal Investigator), Alaa Abdalla, Ashish a preliminary framework for understanding how students conceptualise their own achievement has emerged (for a fuller explanation see McArthur, 2020). In this framework there is a spectrum of how students understand their achievement in terms of the broader society: in the phrase coined as part of assessment for social justice (McArthur, 2018) how responsive is their perception of the assessment practice to the wider social world. At one end there is achievement represented simply in terms of the mark received. Thus, achievement is getting an $\mathrm{A}$ or $60 \%$ or being on track for a first-class degree, as though any of these are ends in themselves. There is no link to either engagement with knowledge, a broader sense of personal achievement or wider society. But this account, based on the UK first year data so far, is unusual. The vast majority of students associated achievement in some way with knowledge acquired, but there is a spectrum here. First, is simply achievement in the sense of having gained a piece of knowledge - e.g. the properties of a particular molecule. Gaining this knowledge is, for these students, a positive thing and hence an achievement. Next comes the practical application of the knowledge learned; something highly valued in both these disciplines. Thus they have learned about a molecule and can apply that knowledge to do something else they value. Then some students projected this further, and placed value in learning knowledge which they could practically apply, and which would be considered useful later to apply in industry or society (though generally these students talked in terms of industry). So here we have the practical application of knowledge learned in the social sphere. The final point of the spectrum seems to me to be the practical application of knowledge learned in the social sphere and for the social good - and this is what brings us closest to Honneth's esteem recognition. Thus this, I argue, should be our

Agrawal, Margaret Blackie, Jenni Case, Benjamin Goldschneider, Janja Komlijenovic, Jan McArthur, Nicole Pitterson, Kayleigh Rosewell and Renee Smit 
goal if we want to enable the full development of our student as a social being through engagement with assessment practices. No students in the UK data analysed so far explicitly identified with this last category, though there are indications in the South African data that some students there did so. For example, students speaking about their commitment to learning Chemistry because they may go on to use that knowledge in the pharmaceutical industry and contribute to something socially-useful such as a new drug for malaria. These students clearly position their anticipated achievement in terms of the social value of their work, and not simply economic return.

In contrast, a student who sees their achievement solely in terms of a disembodied mark or grade point average denies themselves the full sense of achievement from engagement with socially useful knowledge. But more than this, the critical theory interconnection between individual and social wellbeing suggests that true individual fulfilment comes through this social application and engagement. It is not simply that the individual act helps society (as may be an interpretation of liberal theory) but rather that through doing something socially useful the student is able to achieve their own fulfilment and potential as an independent human being. This interconnection between independence and others might seem contradictory but is in fact essential to this dialectical understanding of individual and social wellbeing. So if our interest in assessment is our student as a whole person, this must be where we aim. Which is not to say that there cannot be small, discrete tasks along the way. Particularly in the physical sciences the building blocks of knowledge can be important. But there is a distinction between what Hardarson (2017) describes as open and closed aims. Those assessments which encourage the learning of the building blocks of disciplinary knowledge - such as the properties of a particular molecule - involve closed aims: you learn the properties and that is the end of the task. But our eventual aim must be open aims for these are the realm of the complex knowledge that is at the heart of higher education - and its social justice mission. The type of assessments I have referred to - involving socially useful knowledge for the social good - will involve open aims. There will be no one right answer. For example, one cohort of our Chemical Engineering students from the project previously mentioned, undertook a transport project to come up with an environmentallyfriendly way for students to travel between their university campus and the local town. There was no right answer for them: instead, they had to use judgement and explain the rationale for decisions made and the recommendation that ensued. In a broader sense too this is an open aim because on one level we never complete the task of environmentally-friendly transport. It is instead an ongoing challenge.

Thus the second strand in my argument for thinking of assessment in terms of the student as a whole person, rests on the importance of them being able to achieve individual wellbeing through their contribution to social wellbeing. For students at university this may take shape as a future aspiration, as in the case of the South African students wanting to apply their knowledge in the pharmaceutical industry and contribute to an improved drug for malaria. It is not incumbent that they have to be doing this as undergraduate students as that would be unreasonable. But our assessment design should encourage their view to reach to that future horizon and to see the positive contribution they could go on to make within society.

\section{Society and the world of work}

There is a long-standing debate as to whether the purposes of higher education rest on a liberal idea of learning as an end in itself or a more economic view that higher education should contribute to students' employability and the health and wealth of the economic sector in general. This debate is based on a false dichotomy and is ultimately unhelpful for 
understanding both our student as a whole person and how they should be assessed.

From a critical theory perspective higher education should definitely have an explicit economic role, for the economic realm is so central to determining the possibilities for individual and social fulfilment. The problem in many current debates and policy approaches is the way the economic role is often discussed, as I have previously argued (McArthur, 2011), which rests on a narrow interpretation of the economic sphere. Thus there are two issues. Firstly, we should not confuse the economic sphere simply with the rich and powerful government, large business or employers. The poor and marginalised are every bit as much part of the economic realm and their stories also need to be taken into account. Secondly, we should not disarticulate the economic from the social realm by claiming that issues surrounding employment, work, career and wealth are value-neutral or obviously good in themselves. These are all value-laden and immensely problematic aspects of human life. As such, it makes no sense to promote student employability through higher education in any ways that are isolated from social factors and issues of social justice.

The relationship between higher education and the world of work is important. As Winch (2002) has argued so well, work is an important aspect of human wellbeing. That this is the case only proves to underline the normative aspect of work and its social situation. This leads me back to considering assessment and how to involve our student as a whole person. What I am arguing in this section is that understanding our student as a social person involves both an economic and a social identity and it is damaging to disarticulate one from the other. One increasingly popular approach to assessment, which does seem to recognise the student as a person, is the use of authentic assessment. This is an important movement in assessment practice, but one about which I would like to offer a critique.
Authentic assessment is most commonly described as assessment based in 'real world' tasks. On the surface, this fits very well with the idea of responsive assessments discussed in the previous section. However, I am concerned that the literature on authentic assessment is inadvertently perpetuating a narrow view of the economic sphere, disarticulated from society. Reviewing a range of literature (e.g. Ashford-Rowe et al., 2014; Eddy \& Lawrence, 2013; James \& Casidy, 2018; Raymond et al., 2013; Villarroel et al., 2018) that claimed to be about authentic assessment in higher education I found that much of this was actually focused on the world of work, not the 'real world' as a whole or in fact conflated the two and assumed real world tasks were simply work-based tasks . For example, 'authentic assessment aims to integrate what happens in the classroom with employment' (Villarroel et al., 2018, p. 841). Similarly, James and Casidy (2018) consider employer expectations of higher education and associate authentic assessment with a conflated understanding of the real world as the world of work. This is hugely problematic for the two reasons already outlined: the economic sphere should not be reduced to simply what employers want and the economic sphere cannot be disarticulated from the social.

If we return to thinking of our student as a whole person, her personal fulfilment does not come in being a passive and compliant worker. By this I do not mean to demonise all employers as only wanting passive and compliant workers. However, there is a dangerous discourse in higher education, and in government policy, that suggests that higher education should do more to provide what employers want. This is tricky territory. Of course higher education is about contributing to the professional workforce which is vital for many social roles and institutions, as well we economic health. But this is not the same as repositioning higher education as some sort of de facto employment agency responsible for slotting the right student into the right employment vacancy. I return to the first main section of this article and the importance of 
engagement with complex knowledge to the purposes of higher education. And to the embodied nature of this knowledge, which changes the knower and is changed by the knower. Previously I've explained this in terms of the metaphor of a palimpsest (McArthur, 2012, 2013) which refers to a manuscript in which older writing has been written over, but remains in trace. I have used this to argue that students should be able to leave their trace, make their mark, on disciplinary knowledge if they are to be genuinely, seriously engaged with it. In a similar vein, I would like to extend the idea to who our students are when they go out into the world of work. A genuine criticality suggests that the former student brings something of their own to the workplace, and it may not be what the employer necessarily anticipated. But the genuine engagement with complex knowledge that, I have argued, defines what happens within higher education should also define what happens when our graduates leave and begin work.

Too much of the discussion about students' preparation for work is one-sided and views students, and by implication universities, as the problem. In other words, employers are not getting the employees they want and universities should respond to this: students should let themselves be fashioned into what the employers want. And this is one of the arguments put forward for authentic assessment. However, from a critical theory perspective, employment should be a relationship of equals; working should be an expression, in part, of our individual selfworth. Here we would have genuine authenticity, because it would be about the authenticity of the student as a person, not simply a particular task. The problems facing society, and our economic spheres, will require creative and flexible minds able to engage with complex problems and offer genuine solutions. But to achieve this in reality, rather than as a feel-good slogan or mission statement, requires a rethinking of the economic role of the graduate worker and a genuine respect for what they bring to their role. Assessment should encourage both the confidence to do this and the necessary judgement to see their own contributions in the context of others.

Ashford-Rowe et al. (2014) broaden the understanding of authentic assessment to not just be about real world tasks - but to involve genuine intellectual challenge. In addition, they argue it should involve the production of an actual performance or product - though how the latter is defined is, I suggest, subject to debate. Echoing other conceptualisations of authentic assessment as work-related, these authors also state that authentic assessment should involve the transfer of knowledge: in other words, the ability to apply and use it another context. This notion of genuine intellectual challenge is an important addition to our understanding of authentic assessment and relates back to the first theme regarding the nature of knowledge in higher education and in our assessment practices.

What is still missing, however, is a sociallysituated understanding of these real world tasks in the sense of an acknowledgement of the problematic nature of society, riven as it is with power imbalances, inequality and injustice. I have only found one article on authentic assessment which explicitly makes this link - a thoughtful account of practice from two historians in Australia (see Forsyth \& Evans, 2019). Forsyth and Evans take a more expansive sense of real world tasks to address the problems of more inclusive epistemologies and pedagogies within the context of postcolonialism. In Australia the once neglected value of indigenous histories provides a marked example of narrow and exclusionary epistemologies. Closely associated with this is the move towards more participatory, and hence inclusive, approaches to history.

Thus Forsyth and Evan's aim is to 'to transform, not just replicate, the discipline '( $p$. 749) - which leads them to critically reconsider what is meant by authenticity - and particularly whose authenticity is it? They assert that traditional approaches to teaching can mask conservative and homogeneous disciplinary traits - even though there is a rich 
stream of history which now deals with decolonisation and the global south. These social justice issues may be more easily seen in a discipline such as history, but they permeate every discipline within the university in equal measure. I am reminded of the response some chemistry and chemical engineering academics made when we introduced the project outlined earlier, explaining it in terms of these disciplines being what Biglan (1973) famously classified as 'non-life' disciplines. They were appalled at the idea that their disciplines were considered unrelated to human activity and argued instead for their centrality to human affairs. Surely this should be the case in every discipline within the university; that its members see this fundamental link between what they do and the social sphere? And important as the world of work is to this, it does not define it on its own, nor should it define us or our students.

\section{Conclusion}

Student involvement in assessment means so much more than them undertaking discrete tasks. If we truly believe in the power of the idea behind assessment for learning and the importance of assessment for students' future lives, then we must think of the relationship between assessment and our students as whole people, socially situated. We must also recognise that the social world, which incorporates the economic, is not benign but rather is the creation of multiple forces and interests. It is hugely problematic to assert that assessment should prepare students for the 'real world' and yet to work with an understanding of that world which is partial, homogenised and sanitised. The real world is complex not just because the problems students will encounter in work are complex, but because it is made up of many competing social forces, not all of which are kind or fair.

Thus the common argument, for example, that students should engage in group work assessment tasks because they are likely to have to work in teams when they leave university only reflects part of reality.
Students' connections to others goes well beyond the teams in an employment setting and stretches to all corners of the social world. If higher education is to fulfil its social justice mission, it must help develop students as knowledgeable, compassionate and active members of this social whole - and assessment plays an important part in this process.

Returning to the example of group work, the danger with the way in which some assessment initiatives are introduced in higher education lies in paying lip service to student agency while actually contributing to a culture of conformity. Indeed, McGarr and Clifford (2013) note that the ways in which peer and self assessment have been promoted often involve forced participation that is counterintuitive to the narrative of greater student agency. Students undertake these roles because they are told they have to. "Do it. It will do you good." Thus, returning to the student as a whole person, and their relationship to assessment, this means thinking beyond simply which assessment techniques to use, and considering instead the whole student experience of them, and how this relates to future lives.

Assessment is notoriously immune to radical change. For many this is because assessment matters so much. It is too important to fiddle with or think differently about. But if we never think differently, then nothing will ever change. A commitment to critical pedagogy and social justice education begins with a recognition that we need change: that the world as it is currently organised is unjust (McLean, 2006). In this context, the need to radically think differently about assessment is not only essential but urgent.

\section{Acknowledgement}

Research discussed in this article was made possible by funding from the ESRC award ES/M010082/1, and the ESRC/OFSRE Centre for Global Higher Education.

\section{References}


Adorno, T. W. (2001). Kant's Critique of Pure Reason (1959). Polity.

Ashford-Rowe, K., Herrington, J., \& Brown, C. (2014). Establishing the critical elements that determine authentic assessment. Assessment and Evaluation in Higher Education, 39(2), 205-222.

https://doi.org/10.1080/02602938.2013.81956 $\underline{6}$

Ashwin, P. (2014). Knowledge, curriculum and student understanding in higher education. Higher Education, 67, 123-126. https://doi.org/10.1007/s10734-014-9715-3

Ashwin, P., Abbas, A., \& McLean, M. (2012). The pedagogic device: Sociology, knowledge practice and teaching-learning processes. In P. Trowler, M. Saunders, \& V. Bamber (Eds.), Tribes and Territories in the 21st century: rethinking the significance of disciplines in higher education (pp. 118-129). Routledge.

Bernstein, B. (2000). Pedagogy, Symbolic Control and Identity. Rowman and Littlefield.

Biglan, A. (1973). The Characteristics of Subject Matter in Different Academic Areas. Journal of Applied Psychology, 57(3), 195203. https://doi.org/10.1037/h0034701

Boud, D., Cohen, R., \& Sampson, J. (1999). Peer Learning and Assessment. Assessment \& Evaluation in Higher Education, 24(4), 413426.

https://doi.org/10.1080/0260293990240405

Bovill, C. (2013). Staff-student partnerships in higher education. Educational Review, 65(3), 380-382.

https://doi.org/10.1080/00131911.2012.65945 4

Bovill, C., Bulley, C. J., \& Morss, K. (2011). Engaging and Empowering First-Year Students through Curriculum Design: Perspectives from the Literature. Teaching in Higher Education, 16(2), 197-209. https://doi.org/10.1080/13562517.2010.51502 4

Bovill, C., Cook-Sather, A., \& Felten, P. (2011). Students as Co-Creators of Teaching
Approaches, Course Design, and Curricula: Implications for Academic Developers. International Journal for Academic Development, $\quad$ 16(2), 133-145. https://doi.org/10.1080/1360144X.2011.5686 90

Brown, J. S., \& Duguid, P. (2000). The Social Life of Information. Harvard Business School Press.

Carless, D., \& Boud, D. (2018). The development of student feedback literacy: enabling uptake of feedback. Assessment and Evaluation in Higher Education, 43(8), 13151325.

https://doi.org/10.1080/02602938.2018.14633 54

Deeley, S. J., \& Bovill, C. (2017). Student-staff partnership in assessment: enhancing assessment literacy through democratic practices. Assessment and Evaluation in Higher Education, 42(3), 463-477. https://doi.org/10.1080/02602938.2015.11265 51

Douglas Smith, C., Worsfold, K., Davies, L., Fisher, R., \& McPhail, R. (2013). Assessment literacy and student learning: the case for explicitly developing students 'assessment literacy. Assessment and Evaluation in Higher Education, $\quad 38(1), \quad$ 44-60. https://doi.org/10.1080/02602938.2011.59863 $\underline{6}$

Eddy, P. L., \& Lawrence, A. (2013). Wikis as Platforms for Authentic Assessment. Innovative Higher Education, 38, 253-265. https://doi.org/10.1007/s10755-012-9239-7

Falchikov, N., \& Goldfinch, J. (2000). Student Peer Assessment in Higher Education: A Meta-Analysis Comparing Peer and Teacher Marks. Review of Educational Research, 70(3), 287-322. https://doi.org/10.3102/00346543070003287

Forsyth, H., \& Evans, J. (2019). Authentic assessment for a more inclusive history. Higher Education Research and Development, $38(4)$, 748-761. 
https://doi.org/10.1080/07294360.2019.15811 40

Freire, P. (1996). Pedagogy of the Oppressed. Penguin.

Hardarson, A. (2017). Aims of Education: How to Resist the Temptation of Technocratic Models. Journal of Philosophy of Education, 51(1), 59-72. https://doi.org/10.1111/14679752.12182

Honneth, A. (1996). Struggle for Recognition. Polity Press.

Honneth, A. (2003). Redistribution as Recognition: A Response to Nancy Fraser. In N. Fraser \& A. Honneth (Eds.), Redistribution or Recognition? A political-philosophical exchange (pp. 110-197). Verso.

Honneth, A. (2004a). A social pathology of reason: on the intellectual legacy of Critical Theory. In F. Rush (Ed.), The Cambridge Companion to Critical Theory (pp. 336-360). Cambridge University Press. https://doi.org/10.1017/CCOL0521816602.01 4

Honneth, A. (2004b). Recognition and justice: outline of a plural theory of justice. Acta sociologica, 477(4), 351-364. https://doi.org/10.1177/0001699304048668

Honneth, A. (2010). The Political Identity of the Green Movement in Germany: SocialPhilosophical Reflections. Critical Horizons, 11(1), 5-18. https://doi.org/10.1558/crit.v11i1.5

Horkheimer, M. (1993). Between Philosophy and Social Science: Selected Early Writings. The MIT Press. https://doi.org/10.7551/mitpress/1565.001.00 01

James, L. T., \& Casidy, R. (2018). Authentic assessment in business education: its effects on student satisfaction and promoting behaviour. Studies in Higher Education, 43(3), 401-415. https://doi.org/10.1080/03075079.2016.11656 $\underline{59}$

Liu, N.-F., \& Carless, D. (2006). Peer feedback: the learning element of peer assessment.
Teaching in Higher Education, 11(3), 279290.

https://doi.org/10.1080/13562510600680582

McArthur, J. (2011). Reconsidering the social and economic purposes of higher education. Higher Education Research \& Development, 30(6), 737-749. https://doi.org/10.1080/07294360.2010.53959 $\underline{6}$

McArthur, J. (2012). Against standardised experience: leaving our marks on the palimpsests of disciplinary knowledge. Teaching in Higher Education, 17(4), 485496.

https://doi.org/10.1080/13562517.2012.71193 4

McArthur, J. (2013). Rethinking Knowledge in Higher Education: Adorno and Social Justice. Bloomsbury. https://doi.org/ 10.5040/9781472553225

McArthur, J. (2016). Assessment for Social Justice: the role of assessment in achieving social justice. Assessment and Evaluation in Higher Education, 41(7), 967-981. https://doi.org/10.1080/02602938.2015.10534 29

McArthur, J. (2018). Assessment for Social Justice. Perspectives and practices within Higher Education. Bloomsbury. https://doi.org/10.5040/9781474236089

McArthur, J. (2020). Assessment for Social Justice: achievement, uncertainty and recognition. In C. Callender, W. Locke, \& S. Marginson (Eds.), Changing Higher Education for a Changing World. Bloomsbury.

McGarr, O., \& Clifford, A. M. (2013). 'Just enough to make you take it seriously': exploring students' attitudes towards peer assessment. Higher Education, 65, 677-693. https://doi.org/10.1007/s10734-012-9570-Z

McLean, M. (2006). Pedagogy and the University. Critical Theory and Practice. Continuum. 
Norton, L. (2004). Using assessment criteria as learning criteria: a case study in psychology. Assessment \& Evaluation in Higher Education, 29(6), 687-702. https://doi.org/10.1080/026029304200022723 $\underline{6}$

Orsmond, P., Merry, S., \& Reiling, K. (2000). The Use of Student Derived Marking Criteria in Peer and Self-assessment. Assessment \& Evaluation in Higher Education, 25(1), 23-38. https://doi.org/10.1080/02602930050025006

Raymond, J. E., Homer, C. S. E., Smith, R., \& Gray, J. E. (2013). Learning through authentic assessment: An evaluation of a new development in the undergraduate midwifery curriculum. Nurse Education in Practice, 13, 471-476.

https://doi.org/10.1016/j.nepr.2012.10.006
Shay, S. (2008). Beyond social constructivist perspectives on assessment: the centring of knowledge. Teaching in Higher Education, 13(5), 595-605. https://doi.org/10.1080/13562510802334970

Villarroel, V., Bloxham, S., Bruna, D., Bruna, C., \& Herrera-Seda, C. (2018). Authentic assessment: creating a blueprint for course design. Assessment and Evaluation in Higher Education, $\quad 43(5), \quad 840-854$. https://doi.org/10.1080/02602938.2017.14123 96

Winch, C. (2002). Work, Well-being and Vocational Education: The Ethical Significance of Work and Preparation for Work. Journal of Applied Philosophy, 19(3), 261 - 271. https://doi.org/10.1111/14685930.t01-1-00222

\section{Author / Autor}

McArthur, J. (j.mcarthur@lancaster.ac.uk) (DD 0000-0002-9672-4809

Senior Lecturer in the Department of Educational Research in Lancaster University and a research member of the Centre for Global Higher Education. Her main interests in research focus on two themes: education and social justice, and the nature of higher education. Similarly, McArthur has a considerable interest in inter-relationships between education and society, and between theory and practice. She has explored different interpretations of critical pedagogy, and the ways in which the conceptualizations of knowledge impacts on social justice. A great deal of her work relies on the critical theory, and shows a special interest in the work by Theodor Adorno. Her recent work has analyzed the nature of evaluation and feedback and their role of failure in learning including the relationship between conceptions of failure and social justice. In her last book, Assessment for social justice, McArthur explores the potential for promoting social justice within and through assessment in higher education and draws on the critical theory of Axel Honneth.

\section{RELIEVE}

Revista ELectrónica de Investigación y $\mathbf{E V}$ aluación Educativa E-Journal of Educational Research, Assessment and Evaluation [ISSN: 1134-4032]

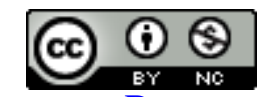

Esta obra tiene licencia de Creative Commons Reconocimiento-NoComercial 4.0 Internacional. This work is under a Creative Commons Attribution 4.0 International license. 